\title{
Broadening the scope of Pd-catalyzed oscillatory carbonylation reactions: solvent, substrate, catalyst
}

\author{
Anna Isakova ${ }^{1} \cdot$ Julie Parker ${ }^{1} \cdot$ Chinyelumndu Jennifer Nwosu $^{1}$. \\ Jonathan Richard Howse ${ }^{2} \cdot$ Katarina Novakovic $^{1}$ (D)
}

Received: 19 December 2018 / Accepted: 4 March 2019 / Published online: 9 March 2019

(c) The Author(s) 2019

\begin{abstract}
On our way to producing all-polymeric self-oscillatory materials, we have expanded the horizons of oscillatory carbonylation reactions by searching for alternative substrates, solvents and even catalysts. In this paper, we demonstrate that $\mathrm{pH}$ oscillations in carbonylation reactions have the potential to occur in a broad range of aliphatic alcohol solutions when using either a small molecule substrate (phenylacetylene) or a polymeric substrate (pegylated alkyne) with either a small molecule catalyst (Pd-diacetate) or a non-leaching polymeric catalyst (Pd-polyacrylate). The alcohols studied are methanol, ethanol, 1-propanol, 1-butanol and 1-hexanol. In this carbonylation reaction an alcohol serves as both the solvent and as a reactant. The resulting oscillations suggest that carbonylation reactions have strong potential for the discovery and development of new oscillatory chemical systems. Replacing methanol, commonly used in oscillatory carbonylation processes, with ethanol is an important step in enhancing the biocompatibility of these systems. Furthermore, showing that oscillations in $\mathrm{pH}$ are feasible in ethanol solutions when polymeric substrate and polymeric catalyst are used supports the vision of employing oscillatory chemical reactions to build oscillatory materials.
\end{abstract}

Keywords Oscillatory chemical reaction · PH oscillations - Carbonylation reaction · Phenylacetylene $\cdot$ Pegylated alkyne $\cdot$ Palladium polyacrylate

Katarina Novakovic

katarina.novakovic@ncl.ac.uk

1 School of Engineering, Newcastle University, Newcastle upon Tyne, UK

2 Chemical and Biological Engineering, Sheffield University, Sheffield, UK 


\section{Introduction}

Fully self-oscillatory materials [1] are materials that are life-like, being able to swell and collapse in a predefined rhythm. Our efforts focus on research advancements that would enable us to efficiently combine intelligent, $\mathrm{pH}$-responsive hydrogels [2-6] with oscillatory chemical reactions [7] in order to produce fully self-oscillatory materials. The ultimate aim is to synthesize robust, autonomous, pulsatile materials with the ability to sustain a rhythmic change in volume and even carry and dispense their content (e.g. drug) in a pre-defined rhythm. The vision behind the development of such autonomous pulsatile materials is to achieve in vivo pulsatile drug delivery, required in chronopharmacotherapy, and mechanoresponsive tissue regeneration. While intelligent hydrogels attract significant interest enhancing progress in that area [8-11], the study of oscillatory chemical reactions [7, 12, 13], particularly oscillatory carbonylation reactions, remains the painstaking effort of a small community [14-20]. The oscillatory palladium-catalyzed oxidative carbonylation reaction $(\mathrm{PCOC})$ readily proceeds under mild temperatures $\left(0-40{ }^{\circ} \mathrm{C}\right)$ and atmospheric pressure in batch and can sustain oscillations in $\mathrm{pH}$, redox properties and turbidity over a prolonged period of time (monitored up to a month) [21, 22]. Commonly, the reaction proceeds in methanol, used both as a solvent and as a reactant, and employs phenylacetylene and carbon monoxide as substrates, $\mathrm{Pd}$ (II) iodide/ $\mathrm{KI}$ as a catalyst and oxygen brought in for catalyst regeneration.

A simplified reaction mechanism that explains the key steps resulting in $\mathrm{pH}$ oscillations includes:

(1) An autocatalytic $\mathrm{pH}$ drop, where $\mathrm{H}^{+}$(from $\mathrm{HI}$ acid) accelerates its own formation while reducing catalyst from $\mathrm{Pd}^{2+}$ to $\mathrm{Pd}^{0}$ :

$$
\mathrm{C}_{6} \mathrm{H}_{5}-\mathrm{C} \equiv \mathrm{CH}+\mathrm{PdI}_{2}+2 \mathrm{CH}_{3} \mathrm{OH}+2 \mathrm{CO} \stackrel{H I}{\longrightarrow} \text { Diester product }+\mathrm{Pd}+2 \mathrm{HI}
$$

(2) Catalyst and HI cycling leading to oscillatory trends:

$$
\begin{gathered}
2 \mathrm{HI}+0.5 \mathrm{O}_{2} \rightarrow \mathrm{I}_{2}+\mathrm{H}_{2} \mathrm{O} \\
\mathrm{Pd}+\mathrm{I}_{2} \rightarrow \mathrm{PdI}_{2}
\end{gathered}
$$

Over the years, we have made a number of advancements in the area of polymeric chemical oscillators within the framework of PCOC. Firstly, we demonstrated polymeric alkyne-terminated polyethylene glycols as viable substrates and proposed a reaction mechanism, which we verified in a modelling study [23]. Secondly, we studied polymer-bound catalytic species, successfully yielding oscillations under a range of conditions using polymeric dicyclohexylphenylphosphine palladium diacetate [24]; chitosan-palladium catalyst (via imine chemistry) [25]; and prolinefunctionalised chitosan-palladium [26]. Here we aim to aid the ongoing efforts of producing an all-polymer oscillating material by reporting studies employing phenylacetylene $(\mathrm{PhAc})$ as a small molecule substrate; monoalkyne functionalized polyethylene glycol (PEGA) as a polymeric substrate; a Pd-diacetate $\left(\mathrm{Pd}(\mathrm{OAc})_{2}\right)$ as a 
small molecule catalyst; and Pd-polyacrylate as a polymeric catalyst. The studies used a broad range of aliphatic alcohols (methanol $(\mathrm{MeOH})$, ethanol (EtOH), 1-propanol (1-PrOH), 1-butanol (1-BuOH) or 1-Hexanol (1-HexOH)), showcasing their ability to yield oscillatory $\mathrm{pH}$ behavior. Importantly, one of the alcohols studied was ethanol, in order to improve the biocompatibility of this oscillatory system.

\section{Experimental}

Reactions were performed at approximately $20{ }^{\circ} \mathrm{C}$ in a flat-bottomed Erlenmeyer flask $(100 \mathrm{~mL})$ with constant stirring. Each flask contained a Pt100 temperature probe and a glass bodied, single ceramic junction combination $\mathrm{pH}$ electrode containing $\mathrm{KCl} / \mathrm{AgCl}$ as the electrolyte and $\mathrm{Ag} / \mathrm{AgCl}$ as the reference. The $\mathrm{pH}$ electrode and temperature probe were connected to a LabVIEW National Instruments system that logged $\mathrm{pH}$ and temperature within the bulk of the reaction mixture. Prior to the reaction, the $\mathrm{pH}$ probes were calibrated at room temperature with aqueous NISTtraceable buffer solutions of $\mathrm{pH} 2,7$ and 10 . KI $(4.150 \mathrm{~g})$ and $\mathrm{Pd}(\mathrm{OAc})_{2}(30 \mathrm{mg})$ were charged into the flask in their solid state and suspended in $100 \mathrm{~mL}$ of solvent $(\mathrm{MeOH}, \mathrm{EtOH}, 1-\mathrm{PrOH}, 1-\mathrm{BuOH}$ or $1-\mathrm{HexOH})$ by stirring. When Pd-polyacrylate [27] was used in place of $\mathrm{Pd}(\mathrm{OAc})_{2}, 200 \mathrm{mg}$ of catalyst was added. The $\mathrm{pH}$ and temperature monitoring started while the KI and catalyst were dissolving and continued throughout the experiment. The $\mathrm{pH}$ was allowed to stabilize. Following this, $\mathrm{CO}$ and air purging $(15 \mathrm{~mL} / \mathrm{min}$ each) through the solution commenced. Once the $\mathrm{pH}$ value had stabilized following an initial $\mathrm{pH}$ drop, substrate was added. Either PhAc (1.38 mL, $12.57 \mathrm{mmol})$ or PEGA (130 mg, $0.62 \mathrm{mmol})$, synthesised according to previous reports from $2000 \mathrm{~g} / \mathrm{mol}$ polyethylene glycol [28], were used. The study employing PEGA and Pd-polyacrylate in EtOH used $200 \mathrm{mg}$ of Pd-polyacrylate catalyst with three different amounts of PEGA (200, 275 and $350 \mathrm{mg}$ ). In polymeric Pd-polyacrylate the molecules of palladium serve as crosslinkers between the polymer chains, with polyacrylate as a counter ion rather than as a ligand to support palladium [24]. This construct allowed a loading of palladium to be achieved $(2.11 \%$ as determined by inductively-coupled plasma optical emission spectrometry, ICP-OES) and zero leaching of palladium from the catalyst (as determined by ICP-OES, after the reactions). All experiments were duplicated to confirm the results. The equipment allows 6 runs to be conducted in parallel. However, as the substrate was added to each flask manually, substrate addition to each reaction at the exact same time point was not possible so some variation is inevitable.

A sample of the reaction mixtures employing small molecule substrate ( $\mathrm{PhAc})$ was taken at the end of the reaction and analyzed using GC-MS and GC-FID to determine substrate conversion as well as product content. A Varian Saturn 2200 GC-MS-FID fitted with a VF-5 ms column $(30 \mathrm{~m})$ was used. The method was as follows: injector temperature $150{ }^{\circ} \mathrm{C}$; helium flow rate $1 \mathrm{~mL} / \mathrm{min}$; oven temperature $100-195{ }^{\circ} \mathrm{C}$ over 35 min in 5 steps followed by a hold. FID analysis used the same GC method with a detector temperature of $300^{\circ} \mathrm{C}$ and gas flow rates of nitrogen $=30 \mathrm{~mL} / \mathrm{min}$; hydrogen $=30 \mathrm{~mL} / \mathrm{min}$ and air $=300 \mathrm{~mL} / \mathrm{min}$. Prior to analysis, samples were filtered over silica and then diluted $1: 1$ with a $0.02 \mathrm{M}$ solution 
of naphthalene in methanol. Naphthalene was used as an internal standard for GC analysis. Based on previous $\mathrm{PhAc} / \mathrm{PdI}_{2}$ oscillatory carbonylation studies [29-31] a summarized reaction scheme and anticipated products are given in Fig. 1, where R is the hydrophobic alkyl group from the alcohol.

\section{Results and discussion}

The results are presented in several subsections. The first subsection reports the experimental results recorded using $\mathrm{PhAc}$ as the substrate and $\mathrm{Pd}(\mathrm{OAc})_{2}$ as the catalyst while the second subsection presents data recorded when PhAc was used with Pd-polyacrylate as the catalyst. In both sets of experiments, five different primary alcohols were studied as solvents: $\mathrm{MeOH}, \mathrm{EtOH}, 1-\mathrm{PrOH}, 1-\mathrm{BuOH}$ and 1-HexOH. The final subsection presents experimental studies of PEGA as the substrate and Pdpolyacrylate as the catalyst in $\mathrm{EtOH}$, as this substrate/catalyst/solvent combination is of prime interest for furthering polymeric biocompatible oscillatory systems. As the solvent in these carbonylation reactions also serves as a reactant yielding the formation of esters, studying a range of aliphatic alcohols enables the investigation of the multiple effects of alcohol polarity. When PhAc was used, PhAc conversion, identification and yield of products, were determined using GC-MS and GC-FID as described in the experimental section. In aliphatic alcohols, with the increase in carbon chain length the non-polar carbon chain contribution becomes increasingly relevant. Increasing carbon chain length results in a boiling temperature increase (from $65{ }^{\circ} \mathrm{C}$ for $\mathrm{MeOH}$ to $156{ }^{\circ} \mathrm{C}$ for $1-\mathrm{HexOH}$ ), effectively reducing evaporative solvent loss during lengthy experiments. Of relevance to carbonylation reactions, the

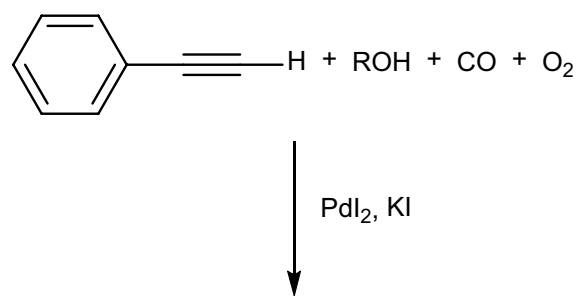

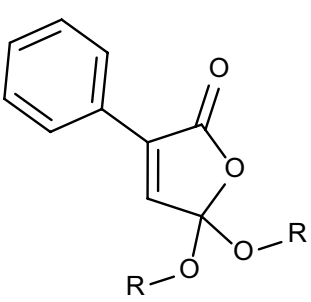

1<smiles>[R]OC(=O)/C=C(\C(=O)O[R])c1ccccc1</smiles>

2<smiles>[R]OC(=O)/C=C(/C(=O)O[R])c1ccccc1</smiles>

3

Fig. 1 Reaction scheme and general products of alkyne carbonylation using $\mathrm{PdI}_{2} / \mathrm{KI}$ catalyst [29-31] 
solubility of $\mathrm{CO}$ and $\mathrm{O}_{2}$ increases as the chain length of the alcohol increases suggesting that gas dissolution is favoured by low-polarity solvents [32]. In the case of $\mathrm{CO}$, solubility ranges from approx. $3.5 \times 10^{-4}$ mol fraction in $\mathrm{MeOH}$ to approx. $6.5 \times 10^{-4} \mathrm{~mol}$ fraction in $1-\mathrm{HexOH}$ at $298.15 \mathrm{~K}$ and $101.3 \mathrm{kPa}$, [33]. In the case of $\mathrm{O}_{2}$, solubility ranges from $4.15 \times 10^{-4} \mathrm{~mol}$ fraction in $\mathrm{MeOH}$ to $9.60 \times 10^{-4} \mathrm{~mol}$ fraction in $1-\mathrm{HexOH}$ at $298.2 \mathrm{~K}$ and $101.3 \mathrm{kPa}$ [34].

\section{Oxidative carbonylation of $\mathrm{PhAc} / \mathrm{Pd}(\mathrm{OAc})_{2}$ in $\mathrm{MeOH}$, EtOH, 1-PrOH, 1-BuOH and 1-HexOH}

This section details $\mathrm{pH}$ trends recorded in experimental studies of oxidative carbonylation using the small molecule substrate, PhAc, and the small molecule catalyst, $\mathrm{Pd}(\mathrm{OAc})_{2}$, in a range of alcohols. As can be noted from Fig. 2, resulting $\mathrm{pH}$ behaviour differs in different solvents. An initial $\mathrm{pH}$ drop (first $70 \mathrm{~min}$ ) is induced by $\mathrm{CO}$ purging and is associated with the discoloration of the reaction solution, indicating the incorporation of $\mathrm{CO}$ into the structure of the $\mathrm{Pd}(\mathrm{OAc})_{2}$ catalyst. Following this, the autocatalytic $\mathrm{pH}$ drop is related to the addition of substrate (added in the first $100 \mathrm{~min}$ ). A fast drop occurs in $\mathrm{MeOH}, \mathrm{EtOH}$ and 1-PrOH. The $\mathrm{pH}$ drop is also present but somewhat slower in $1-\mathrm{BuOH}$ while a limited $\mathrm{pH}$ drop is recorded in $1-\mathrm{HexOH}$. The rate of the $\mathrm{pH}$ drop is an indication of the rate of initial autocatalytic hydrogen ion formation and observed trends could suggest that this rate decreases in $1-\mathrm{BuOH}$ and further slows down in $1-\mathrm{HexOH}$, indicating the effect of the increase in aliphatic alcohol chain length. While this may be the case, further studies seeking to correlate recorded $\mathrm{pH}$ with hydrogen ion concentration are needed to confirm this given that the $\mathrm{pH}$ of non-aqueous solutions is being recorded using aqueous $\mathrm{pH}$

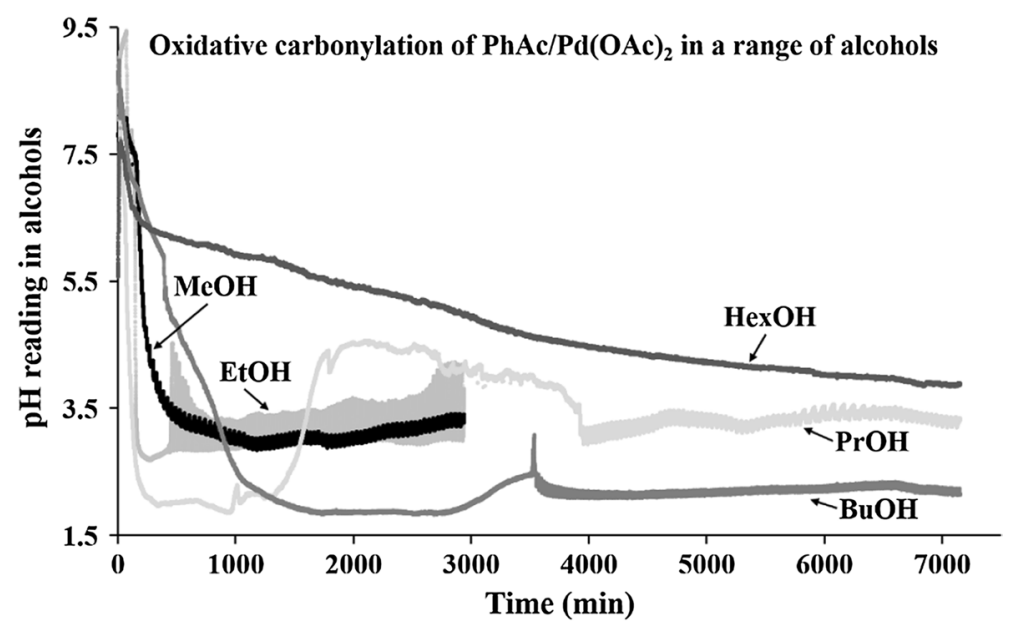

Fig. $2 \mathrm{pH}$ recorded in the PCOC of phenylacetylene in methanol, ethanol, 1-propanol, 1-butanol and 1-hexanol. $[\mathrm{PhAc}]=12.57 \mathrm{mmol} ;[\mathrm{KI}]=250 \mathrm{mmol} ;\left[\mathrm{Pd}(\mathrm{OAc})_{2}\right]=1.34 \mathrm{mmol} ; \mathrm{ROH}=100 \mathrm{~mL}$; $\mathrm{CO}=15 \mathrm{~mL} / \mathrm{min}$ and air $=15 \mathrm{~mL} / \mathrm{min}$ 
electrodes $[35,36]$. Oscillations in $\mathrm{pH}$ were recorded in $\mathrm{MeOH}, \mathrm{EtOH}, 1-\mathrm{PrOH}$ and 1-BuOH. Oscillations were not observed in 1-HexOH under the conditions studied.

To look into the $\mathrm{pH}$ trends captured in Fig. 2, different segments of the recorded data are presented in Figs. 3 and 4. Fig. 3 shows the oscillations in $\mathrm{pH}$ recorded in the experiments using $\mathrm{PhAc}$ in $\mathrm{MeOH}$ and EtOH.

While oscillations in $\mathrm{pH}$ in the $\mathrm{PhAc}-\mathrm{Pd}(\mathrm{OAc})_{2}-\mathrm{MeOH}$ carbonylation reaction system have been previously reported [24], confirming that oscillations can be achieved in $\mathrm{EtOH}$ is a significant addition to the family of oscillatory carbonylation oscillators. Compared to methanol, ethanol is of lower cytotoxicity, can be readily used in vivo as it is currently used for sterilization treatment of biodegradable scaffolds [37] and therefore is better suited as a building block for self-oscillatory materials. In both solvents, oscillations commence upon the initial autocatalytic fall in $\mathrm{pH}$ (first $300 \mathrm{~min}$ ). It can be noted that in $\mathrm{MeOH}$ oscillations started during the $\mathrm{pH}$ fall, a feature we have occasionally observed in $\mathrm{PhAc}-\mathrm{Pd}(\mathrm{II})$ iodide PCOC reactions in $\mathrm{MeOH}[16,21]$. In EtOH, oscillations started once the initial $\mathrm{pH}$ fall was completed and a slow $\mathrm{pH}$ increase had commenced. This is similar to trends observed in the majority of $\mathrm{PhAc}-\mathrm{Pd}(\mathrm{II})$ iodide-MeOH studies previously reported [30]. Interestingly, $\mathrm{pH}$ oscillations in $\mathrm{EtOH}$ promptly increased in amplitude. In both $\mathrm{MeOH}$ and $\mathrm{EtOH}$, oscillations were sustained beyond the duration of the experiments (recording stopped at approximately $3000 \mathrm{~min}$ ). While oscillating in a similar $\mathrm{pH}$ region (3-5) amplitudes recorded in $\mathrm{MEOH}$ were smaller (approx. 0.2-0.3) than in $\mathrm{EtOH}$ (approximately 0.4-1.7). On the other hand, periods were larger in $\mathrm{MeOH}$ (40-45 min) than in EtOH (23-26 min).

In Fig. 4, pH recorded in the experiments using 1-PrOH and 1-BuOH shows similar behavior to some extent. In both studies oscillations started much later in the run

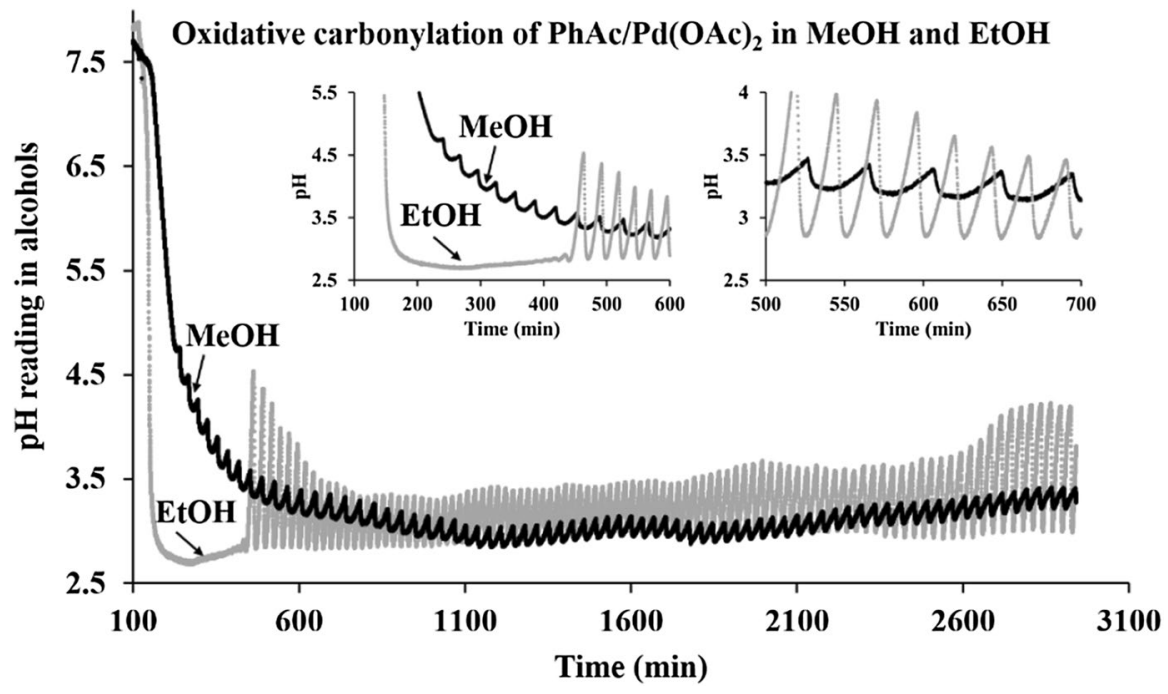

Fig. $3 \mathrm{pH}$ recorded in the PCOC of phenylacetylene in methanol (black), ethanol (grey). $[\mathrm{PhAc}]=12.57 \mathrm{mmol} ;[\mathrm{KI}]=250 \mathrm{mmol} ;\left[\mathrm{Pd}(\mathrm{OAc})_{2}\right]=1.34 \mathrm{mmol} ; \mathrm{ROH}=100 \mathrm{~mL} ; \mathrm{CO}=15 \mathrm{~mL} / \mathrm{min}$ and air $=15 \mathrm{~mL} / \mathrm{min}$ 


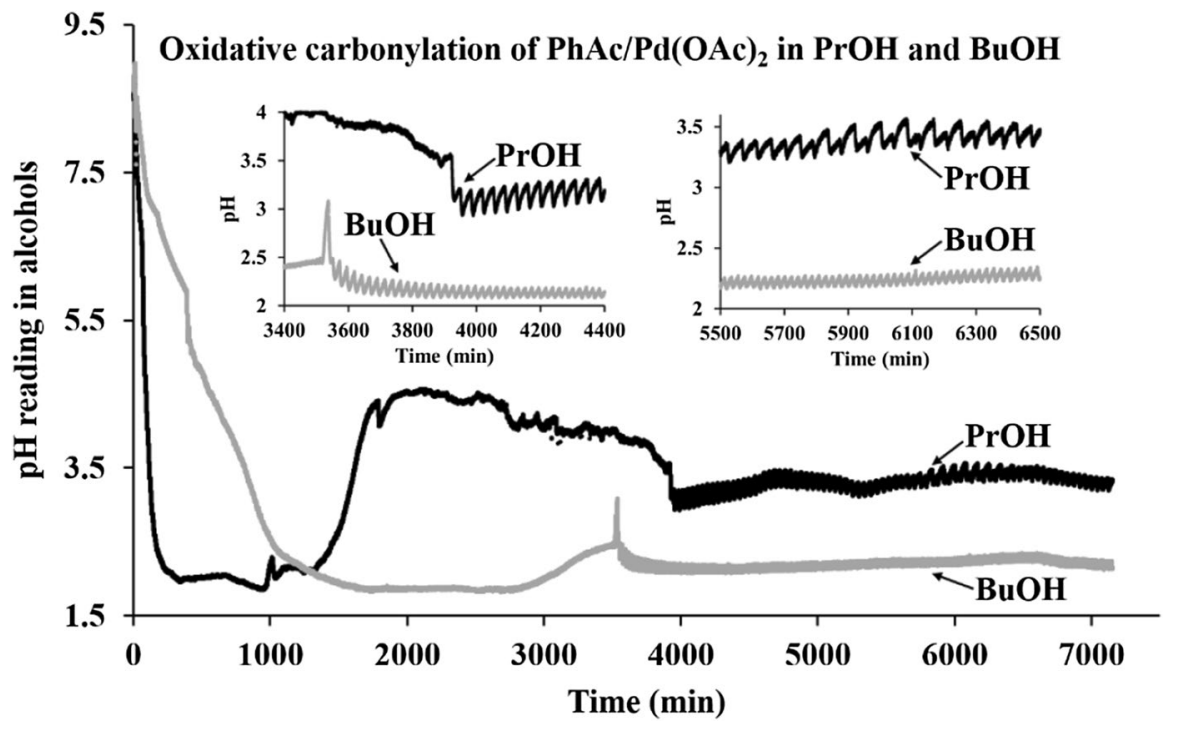

Fig. $4 \mathrm{pH}$ recorded in the PCOC of phenylacetylene in 1-propanol (black) and 1-butanol (grey). $[\mathrm{PhAc}]=12.57 \mathrm{mmol} ;[\mathrm{KI}]=250 \mathrm{mmol} ;\left[\mathrm{Pd}(\mathrm{OAc})_{2}\right]=1.34 \mathrm{mmol} ; \mathrm{ROH}=100 \mathrm{~mL} ; \mathrm{CO}=15 \mathrm{~mL} / \mathrm{min}$ and air $=15 \mathrm{~mL} / \mathrm{min}$

(3490 min in 1-BuOH and $3922 \mathrm{~min}$ in 1-PrOH) once the initial $\mathrm{pH}$ fell, reached a minimum and commenced recovery. Oscillations were observed in the $\mathrm{pH}$ region of 2.9-3.5 in 1-PrOH and 2.1-3 in 1-BuOH, with amplitudes ranging from 0.1 to 0.25 in $1-\mathrm{Pr}-\mathrm{OH}$ and $0.04-0.64$ in $1-\mathrm{BuOH}$. The period of oscillations was longer in $1-\mathrm{PrOH}(32-53 \mathrm{~min})$ than in $1-\mathrm{BuOH}(21-36 \mathrm{~min})$.

\section{Oxidative carbonylation of PhAc/Pd-polyacrylate in MeOH, EtOH, 1-PrOH, 1-BuOH and 1-HexOH}

As can be noted from Fig. 5, when employing PhAc as the substrate and Pd-polyacrylate as the catalyst, oscillations in $\mathrm{pH}$ were recorded in all the solvents studied $(\mathrm{MeOH}, \mathrm{EtOH}, 1-\mathrm{PrOH}, 1-\mathrm{BuOH}$ and $1-\mathrm{HexOH})$. Yet, the oscillatory trends captured differed in different solvents.

To have a closer look into the recorded oscillations, the $\mathrm{pH}$ recorded in $\mathrm{MeOH}$ and $\mathrm{EtOH}$ is plotted in Fig. 6, while the $\mathrm{pH}$ recorded in 1-PrOH, 1-BuOH and $1-\mathrm{HexOH}$ is given in Fig. 7.

Fig. 6 reveals some unusual oscillatory trends. In $\mathrm{MeOH}$, oscillations commenced around 500 min into the reaction and initially had a bursting trend [38]. The bursts of oscillations were initially approximately $300 \mathrm{~min}$ apart, with the gap between them shortening and then disappearing over time. On the other hand, oscillations in EtOH start promptly upon the initial $\mathrm{pH}$ fall and are mixed-mode in nature [39]. During the run in EtOH, the amplitude of the oscillations changes and what appears as a set of larger amplitude mixed-mode 


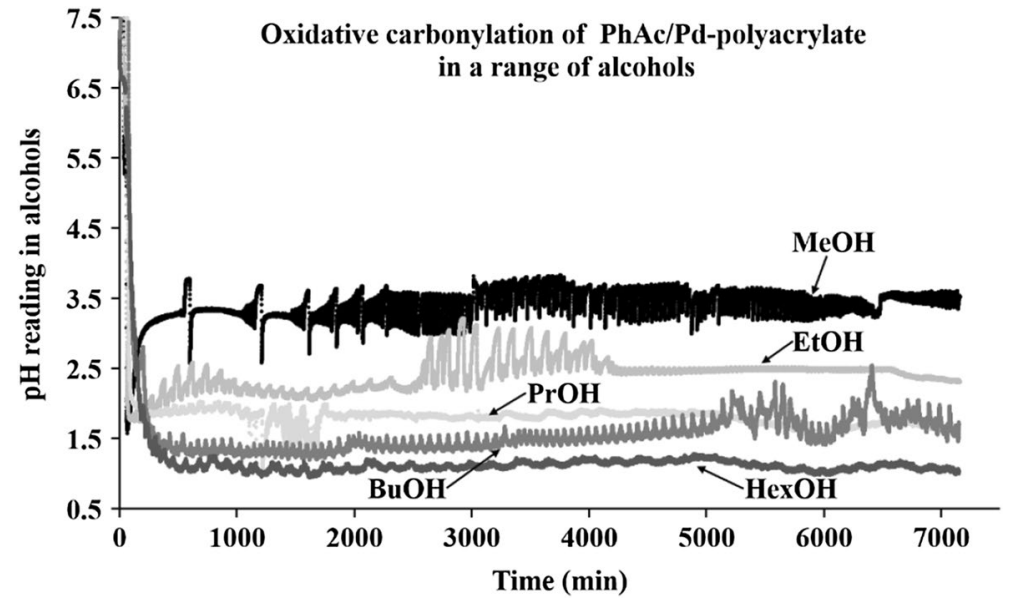

Fig. $5 \mathrm{pH}$ recorded in the oxidative carbonylation reaction using $\mathrm{PhAc} / \mathrm{Pd}$-polyacrylate in $\mathrm{MeOH}, \mathrm{EtOH}$, 1-PrOH, 1-BuOH and 1-HexOH. $[\mathrm{PhAc}]=12.57 \mathrm{mmol} ;[\mathrm{KI}]=250 \mathrm{mmol}$; Pd-polyacrylate $=200 \mathrm{mg}$; $\mathrm{ROH}=100 \mathrm{~mL} ; \mathrm{CO}=15 \mathrm{~mL} / \mathrm{min}$ and air $=15 \mathrm{~mL} / \mathrm{min}$

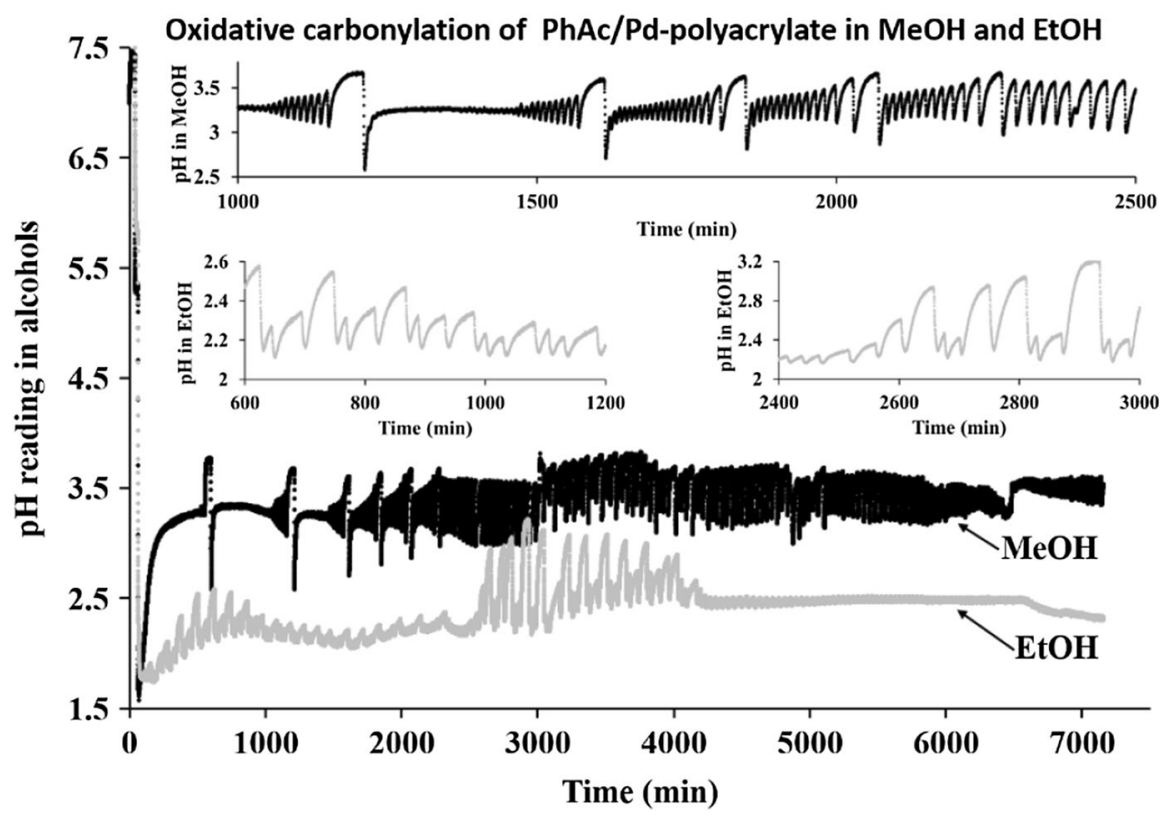

Fig. $6 \mathrm{pH}$ recorded in the oxidative carbonylation reaction using $\mathrm{PhAc} / \mathrm{Pd}$-polyacrylate in $\mathrm{MeOH}$ (black), and EtOH (grey) $[\mathrm{PhAc}]=12.57 \mathrm{mmol} ;[\mathrm{KI}]=250 \mathrm{mmol} ;$ Pd-polyacrylate $=200 \mathrm{mg} ; \mathrm{ROH}=100 \mathrm{~mL}$; $\mathrm{CO}=15 \mathrm{~mL} / \mathrm{min}$ and air $=15 \mathrm{~mL} / \mathrm{min}$

oscillations is recorded between 2600 and $4100 \mathrm{~min}$. The amplitudes of the $\mathrm{pH}$ oscillations recorded in both $\mathrm{MEOH}$ and $\mathrm{EtOH}$ range from very small (approx. 0.04 ) to approximately $1 \mathrm{pH}$ unit. Periods of oscillations in $\mathrm{MeOH}$ range from 


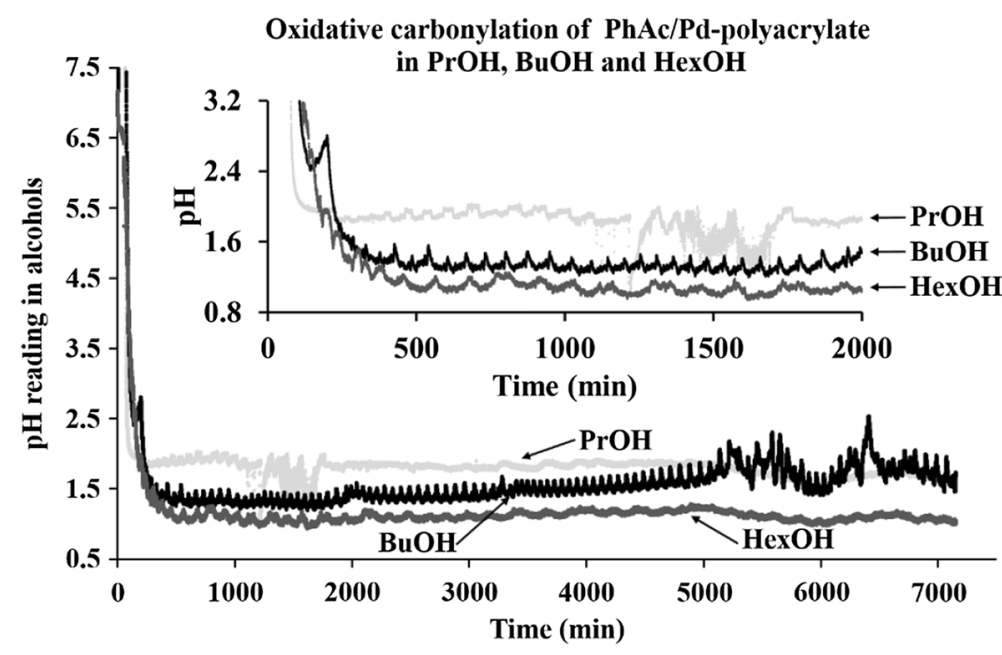

Fig. $7 \mathrm{pH}$ recorded in the oxidative carbonylation reaction using $\mathrm{PhAc} / \mathrm{Pd}$-polyacrylate in 1-PrOH, $1-\mathrm{BuOH}$ and 1-HexOH. $[\mathrm{PhAc}]=12.57 \mathrm{mmol} ; \quad[\mathrm{KI}]=250 \mathrm{mmol} ; \quad$ Pd-polyacrylate $=200 \mathrm{mg}$; $\mathrm{ROH}=100 \mathrm{~mL} ; \mathrm{CO}=15 \mathrm{~mL} / \mathrm{min}$ and air $=15 \mathrm{~mL} / \mathrm{min}$

approximately 10-60 min while in EtOH recorded periods range from approx. 14-83 min. Compared to $\mathrm{Pd}(\mathrm{OAc})_{2}$ catalyzed $\mathrm{PhAc}$ carbonylations in $\mathrm{MeOH}$ and $\mathrm{EtOH}$ ("Oxidative carbonylation of $\mathrm{PhAc} / \mathrm{Pd}(\mathrm{OAc})_{2}$ in $\mathrm{MeOH}, \mathrm{EtOH}, 1-\mathrm{PrOH}$, 1-BuOH and 1-HexOH"), $\mathrm{pH}$ oscillations recorded when Pd-polyacrylate was used have a broader range of periods.

As can be seen from Fig. 7, when experiments were performed in 1-PrOH, $1-\mathrm{BuOH}$ and $1-\mathrm{HexOH}$, oscillations commenced promptly at the very end of the initial $\mathrm{pH}$ fall. Contrary to the study employing $\mathrm{Pd}(\mathrm{OAc})_{2}$, the initial $\mathrm{pH}$ fall is largest in $1-\mathrm{HexOH}$, followed by $1-\mathrm{BuOH}$ and $1-\mathrm{PrOH}$ (and then EtOH followed by $\mathrm{MeOH}$, Figs. 5, 6) potentially suggesting that when Pd-polyacrylate was used the longer the aliphatic chain of the alcohol, the faster the initial autocatalytic rate of $\mathrm{pH}$ drop. While in all three alcohols oscillations have small amplitudes (below $0.5 \mathrm{pH}$ units) their shape is very different. In 1-PrOH, oscillations initially have a "square" shape, followed by an unusually noisy section (1220-1700 min). In 1-BuOH, from their onset oscillations appear to be mixed-mode, with amplitude increasing towards the end of the experiment. In 1-HexOH, while most certainly present, oscillations are of a more irregular nature. Compared to similar studies employing $\mathrm{Pd}(\mathrm{OAc})_{2}$ ("Oxidative carbonylation of $\mathrm{PhAc} / \mathrm{Pd}(\mathrm{OAc})_{2}$ in $\mathrm{MeOH}$, EtOH, 1-PrOH, 1-BuOH and 1-HexOH”), the observed periods of oscillations have a broader range and are generally longer. Periods range from 20 to $263 \mathrm{~min}$ in 1-PrOH and 13-44 min in 1-BuOH. While previously when $\mathrm{Pd}(\mathrm{OAc})_{2}$ was used oscillations in 1 -HexOH were not recorded, oscillations in 1-HexOH captured when $\mathrm{Pd}$-polyacrylate was used had periods ranging from 31 to $156 \mathrm{~min}$. 


\section{PhAc conversion to products}

The associated PhAc conversion to products when $\mathrm{Pd}(\mathrm{OAc})_{2}$ was used as the catalyst was $27 \%$ in $\mathrm{MeOH}, 24 \%$ in $\mathrm{ETOH}, 38 \%$ in $1-\mathrm{PrOH}$ and $39 \%$ in $1-\mathrm{BuOH}$. The $\mathrm{PhAc}$ conversion in $1-\mathrm{HexOH}$ was not accurately quantifiable due to the co-elution of the phenylacetylene and 1-hexanol peaks, however it was very low as the analysis showed very little product formation compared to the other alcohols. When Pd-polyacrylate was employed as the catalyst PhAc conversions recorded were 37\% in $\mathrm{MeOH}, 40 \%$ in $\mathrm{ETOH}, 37 \%$ in $\mathrm{PrOH}$ and $34 \%$ in 1-BuOH. Again, quantification of $\mathrm{PhAc}$ conversion in 1-HexOH was not possible due to co-elution of the peaks. The distribution of products $\mathbf{1}, \mathbf{2}$, and $\mathbf{3}$ (Fig. 1) for each of the experiments is given in Table 1 and Fig. 8. Products $\mathbf{1}, \mathbf{2}$ and $\mathbf{3}$ were the major products in all experiments except those using Pdpolyacrylate and 1-HexOH where GC-MS analysis indicated a monoester, was the main product. This is possibly hexyl 2-phenylprop-2-enoate or hexyl (2E)3 -phenylprop-2-enoate but further analysis is needed to determine the ester's structure.

The E-diester, 3, is formed in low amounts regardless of the alcohol or catalyst used. This supports previous studies that showed the same trend using $\operatorname{PdI}_{2}$ as the catalyst in methanol [31]. Product $\mathbf{1}$ is formed preferentially over the formation of $\mathbf{2}$ in all alcohols except $\mathrm{MeOH}$. This again is in agreement with the previous studies using $\mathrm{PdI}_{2}$ as the catalyst in methanol [31] that showed a similar product distribution at $20^{\circ} \mathrm{C}$.

Table 1 PhAc conversion and product distributions (\%) in $\mathrm{MeOH}, \mathrm{EtOH}, 1-\mathrm{PrOH}$, $1-\mathrm{BuOH}$ and $1-\mathrm{HexOH}$

\begin{tabular}{lllll}
\hline Experiment & $\begin{array}{l}\text { PhAc conver- } \\
\text { sion }(\%)^{\mathrm{a}}\end{array}$ & \multicolumn{3}{l}{$\begin{array}{l}\text { Product distribu- } \\
\text { tion }(\%)^{\mathrm{b}}\end{array}$} \\
\cline { 3 - 5 } & & $\mathbf{1}$ & $\mathbf{2}$ & $\mathbf{3}$ \\
\hline $\mathrm{Pd}(\mathrm{OAc})_{2}-\mathrm{MeOH}$ & 27 & 39 & 57 & 4 \\
$\mathrm{Pd}(\mathrm{OAc})_{2}-\mathrm{EtOH}$ & 24 & 71 & 22 & 7 \\
$\mathrm{Pd}(\mathrm{OAc})_{2}-1-\mathrm{PrOH}$ & 38 & 56 & 39 & 5 \\
$\mathrm{Pd}(\mathrm{OAc})_{2}-1-\mathrm{BuOH}$ & 39 & 58 & 38 & 4 \\
$\mathrm{Pd}(\mathrm{OAc})_{2}-1-\mathrm{HexOH}$ & $\mathrm{NA}$ & 61 & 36 & 3 \\
$\mathrm{Pd}-$ polyacrylate-MeOH & 37 & 42 & 53 & 5 \\
$\mathrm{Pd}-$ polyacrylate-EtOH & 40 & 68 & 25 & 7 \\
Pd-polyacrylate-1-PrOH & 37 & 79 & 15 & 6 \\
Pd-polyacrylate-1-BuOH & 34 & 65 & 30 & 5 \\
Pd-polyacrylate-1-HexOH & $\mathrm{NA}$ & 37 & 12 & 2 \\
\hline
\end{tabular}

${ }^{\mathrm{a} C a l c u l a t e d ~ f r o m ~ G C-M S}$ analysis

${ }^{\mathrm{b}}$ Calculations were based on the assumption that the FID gave the same response for compounds $\mathbf{1}, \mathbf{2}$ and $\mathbf{3}$

${ }^{\mathrm{c}}$ The distribution of $\mathbf{1}, \mathbf{2}$ and $\mathbf{3}$ is given here for comparison but the main product is monoester ( $49 \%$ of all products formed) 
$\square 1 \square 2 \square 3$

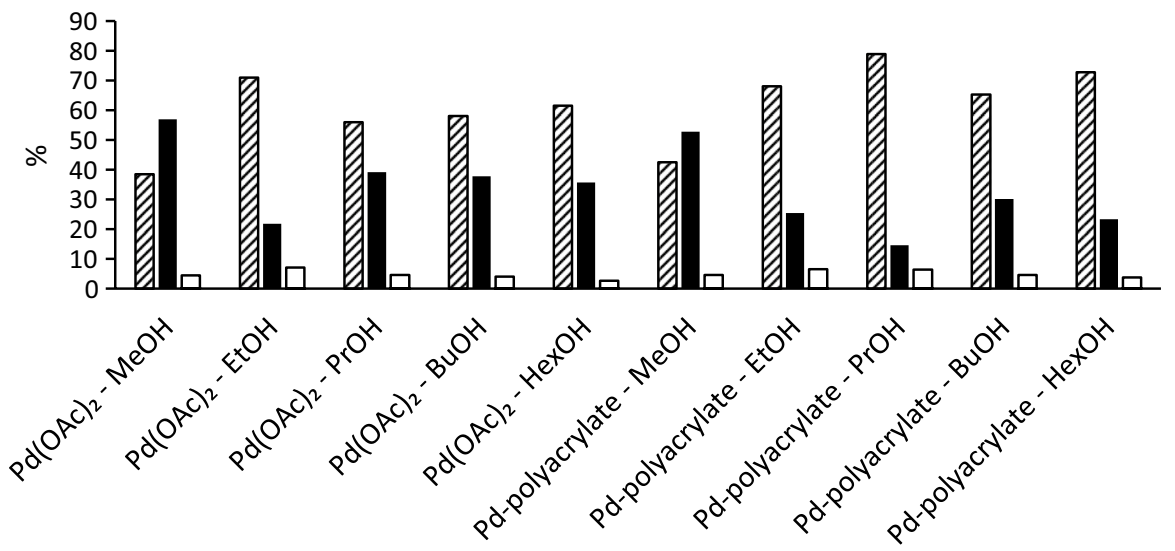

Experiment

Fig. 8 Distribution of products recorded in experiments employing $\mathrm{PhAc}$ as substrate

\section{Oxidative carbonylation of PEGA/Pd-polyacrylate in EtOH}

This section details $\mathrm{pH}$ trends recorded in experimental studies of the oxidative carbonylation reaction using PEGA as the substrate, Pd-polyacrylate as the catalyst, and $\mathrm{EtOH}$ as both reactant and solvent. As can be noted from Fig. 9, upon the initial $\mathrm{pH}$ fall (following PEGA addition) an oscillatory $\mathrm{pH}$ trend commences in all cases

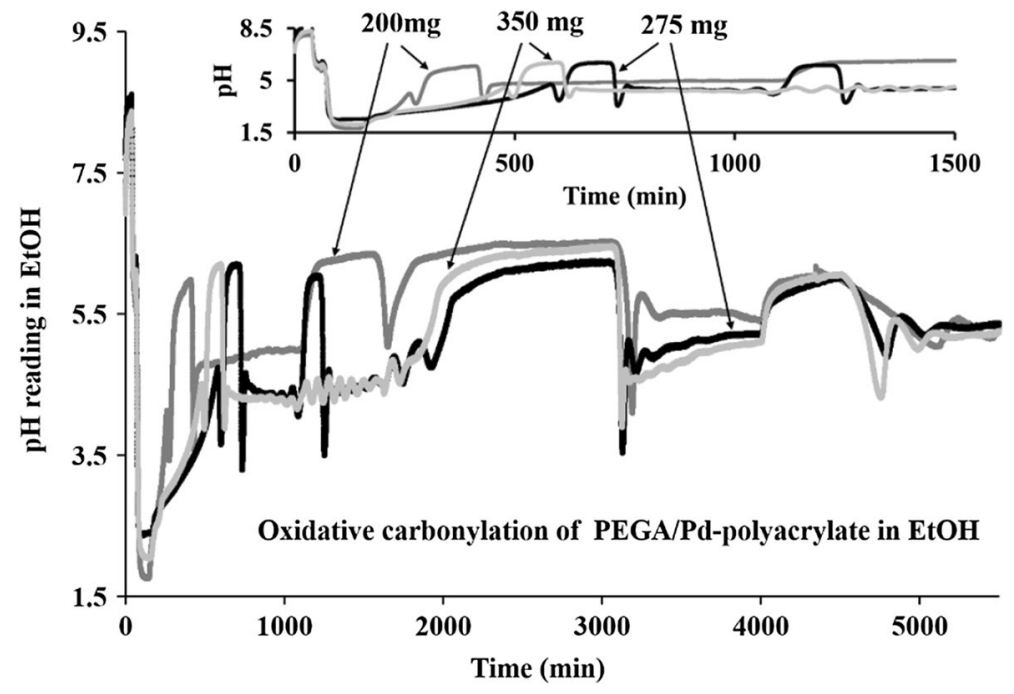

Fig. $9 \mathrm{pH}$ recorded in the oxidative carbonylation reaction using PEGA/Pd-polyacrylate in EtOH. PEGA = $200 \mathrm{mg}, 275 \mathrm{mg}$ and $350 \mathrm{mg} ;[\mathrm{KI}]=250 \mathrm{mmol}$; Pd-polyacrylate $=200 \mathrm{mg}$; EtOH=100 mL; $\mathrm{CO}=15 \mathrm{~mL} / \mathrm{min}$ and air $=15 \mathrm{~mL} / \mathrm{min}$ 
studied. Although in all three experiments similar $\mathrm{pH}$ trends are recorded the fastest $\mathrm{pH}$ recovery upon initial autocatalytic $\mathrm{pH}$ fall occurred when the smallest amount of PEGA was used (200 mg). While oscillations do not fully develop or persist for a significant period of time, these proof of concept studies show that, following the optimization of reaction conditions, this will likely be feasible. Although the change in substrate concentration does affect the reaction dynamic, for the range of PEGA amounts studied these changes are not dramatic. Under the conditions studied the reaction is slow, suggesting that slowly changing the concentration of substrate may not play a major role in related rates of reaction. Further optimization of catalyst concentrations will be pursued to yield oscillatory $\mathrm{pH}$ trends.

\section{Conclusions}

We have demonstrated the versatility of the PCOC reaction by obtaining oscillations in $\mathrm{pH}$ in a broad range of aliphatic alcohols employing both the small molecule substrate phenylacetylene as well as the polymeric substrate monoalkyne functionalized polyethylene glycol in combination with small molecule catalyst Pd-diacetate or polymeric catalyst Pd-polyacrylate. Importantly the monoalkyne functionalized polyethylene glycol/Pd-polyacrylate combination of substrate and catalyst in ethanol showed promise for future exploration in all-polymeric self-oscillating systems. Replacing the commonly used methanol with ethanol is of significance in moving towards more biocompatible oscillatory reaction systems, while using polymers as both substrates and catalyst removes the formation of small products along with the issue of leaching from prospective oscillatory materials. The polymeric Pd-polyacrylate catalyst has a zero leaching rate, which is particularly relevant for the containment of key reacting compounds.

Acknowledgements This work was supported by UK Engineering and Physical Sciences Research Council (EPSRC) Grant Number EP/N033655/1. Data supporting this publication is openly available under an 'Open Data Commons Open Database License'. Additional metadata are available at: https://doi. org/10.17634/153345-3.

Open Access This article is distributed under the terms of the Creative Commons Attribution 4.0 International License (http://creativecommons.org/licenses/by/4.0/), which permits unrestricted use, distribution, and reproduction in any medium, provided you give appropriate credit to the original author(s) and the source, provide a link to the Creative Commons license, and indicate if changes were made.

\section{References}

1. Isakova A, Novakovic K (2017) Oscillatory chemical reactions in the quest for rhythmic motion of smart materials. Eur Polym J 95:430-439

2. Matcham S, Novakovic K (2016) Fluorescence imaging in genipin crosslinked chitosan—poly(vinyl pyrrolidone) hydrogels. Polymers 8:385

3. Marin D, Fairlie M, Bunton P, Nwosu CN, Parker J, Franklin F, Novakovic K (2017) Design and validation study of a laboratory scale chemical reactor for non-invasive imaging of macro objects in situ. Chem Eng J 327:889-897 
4. Nwosu CJ, Hurst GA, Novakovic K (2015) Genipin cross-linked chitosan-polyvinylpyrrolidone hydrogels: influence of composition and postsynthesis treatment on $\mathrm{pH}$ responsive behaviour. Adv Mater Sci Eng 2015:621289

5. Hurst GA, Novakovic K (2013) A facile in situ morphological characterization of smart genipincrosslinked chitosan—poly(vinyl pyrrolidone) hydrogels. J Mater Res 28:2401-2408

6. Chung KY, Birch MA, Novakovic K (2018) Genipin-crosslinked chitosan hydrogels as scaffolds for mammalian cell growth. IJASEAT 6:37-44

7. Epstein IR, Pojman JA (1998) An introduction to nonlinear chemical dynamics: oscillations, waves. Oxford University Press, Patterns and Chaos

8. Ottenbrite RM, Park K, Okano T (2010) Biomedical applications of hydrogels handbook. Springer, New York

9. Novakovic K, Matcham S, Scott A (2018) In: Thakur VJ, Thakur MK (eds) Hydrogels recent advances. Springer, Singapore

10. Vukajlovic DJ, Parker J, Bretcanu O, Novakovic K (2019) Chitosan based polymer/bioglass composites for tissue engineering applications. Mater Sci Eng C 96:955-967

11. Adnadjevic B, Jovanovic J, Lazarevic N (2011) Kinetics study of isothermal nicotine release from poly (acrylic acid) hydrogel. J Appl Polym Sci 119:1805-1812

12. Scott SK, Johnson BR, Taylor AF, Tinsley MR (2000) Complex chemical reactions-a review. Chem Eng Sci 55:209-215

13. Vanag VK, Yang L, Dolnik M, Zhabotinsky AM, Epstein IR (2000) Oscillatory cluster patterns in a homogeneous chemical system with global feedback. Nature 406:389-391

14. Gorodsky SN, Bruk LG, Istomina AE, Kurdiukov AV, Temkin ON (2009) Alkynes carbonylation reactions in solutions of palladium complexes as a new class of oscillatory processes. Top Catal 52:557-562

15. Gorodsky SN (2018) New type of oscillatory processes-oxidative carbonylation of alkynes in the homogeneous catalysis by Pd complexes. Phenylacetylene React Kinet Mech Catal 123:93-112

16. Novakovic K, Grosjean C, Scott SK, Whiting A, Willis MJ, Wright AR (2007) Achieving pH and Qr oscillations in a palladium-catalysed phenylacetylene oxidative carbonylation reaction using an automated reactor system. Chem Phys Lett 435:142-147

17. Novakovic K, Parker J (2011) Catalyst initiation in the oscillatory carbonylation reaction. IJChER 2011:518592

18. Donlon L, Parker J, Novakovic K (2014) Oscillatory carbonylation of phenylacetylene in the absence of externally supplied oxidant. React Kinet Mech Catal 112:1-13

19. Cupic Z, Macesic S, Novakovic K, Anic S, Lj Kolar-Anic (2018) Stoichiometric network analysis of a reaction system with conservation constraints. Chaos 28:083114

20. Macesic S, Cupic Z, Novakovic K, Parker J, Anic S, Lj Kolar-Anic (2019) Oscillatory carbonylation of poly(ethylene glycol)methyl ether acetylene. Modelling of reaction mechanism and stoichiometric network stability analysis. MATCH-COMMUN MATH CO 81:5-34

21. Novakovic K, Mukherjee A, Willis M, Wright A, Scott S (2009) The influence of reaction temperature on the oscillatory behaviour in the palladium-catalysed phenylacetylene oxidative carbonylation reaction. PCCP 11:9044-9049

22. Parker J, Novakovic K (2016) Autonomous reorganisation of the oscillatory phase in the PdI2 catalysed phenylacetylene carbonylation reaction. React Kinet Mech Catal 118:73-85

23. Donlon L, Novakovic K (2014) Oscillatory carbonylation using alkyne-functionalised poly(ethylene glycol). Chem Commun 50:15506-15508

24. Isakova A, Murdoch B, Novakovic K (2018) From small molecules to polymeric catalysts in the oscillatory carbonylation reaction: multiple effects of adding HI. PCCP 20:9281-9288

25. Isakova A, Novakovic K (2018) Pulsatile release from a flat self-oscillating chitosan macrogel. J Mater Chem B 30:5003-5010

26. Isakova A, Parkes GE, Murdoch BJ, Topham PD, Novakovic K (2018) Combining polymer-bound catalyst with polymeric substrate for reproducible $\mathrm{pH}$ oscillations in palladium-catalysed oxidative carbonylation of alkynes. Eur Polym J 109:537-543

27. Rehman SU, Khwaja FA, Ul Haq A, Zafar MS (1994) Concentration dependence of DC conductivity of Pd polyacrylates. Polym Degrad Stab 45:267-272

28. Aj Inglis, Pierrat P, Muller T, Brase S, Barner-Kowollik C (2010) Well-defined star shaped polymerfullerene hybrids via click chemistry. Soft Matter 6:82-84 
29. Grosjean C, Novakovic K, Scott SK, Whiting A, Willis MJ, Wright AR (2008) Product identification and distribution from the oscillatory versus non-oscillatory palladium(II) iodide-catalysed oxidative carbonylation of phenylacetylene. J Mol Catal A Chem 284:33-39

30. Novakovic K, Grosjean C, Scott SK, Whiting A, Willis MJ, Wright AR (2008) The influence of oscillations on product selectivity during the palladium-catalysed phenylacetylene oxidative carbonylation reaction. PCCP 10:749-753

31. Parker J, Novakovic K (2017) The effect of temperature on selectivity in the oscillatory mode of the phenylacetylene oxidative carbonylation reaction. ChemPhysChem 18:1981-1986

32. Tonner SP, Wainwright MS, Trimm DL, Cant NW (1983) Solubility of carbon monoxide in alcohols. J Chem Eng Data 28:59-61

33. IUPAC, Analytical Chemistry Division Commision on Solubility Data. Solubility data series, Vol 43, carbon monoxide. https://srdata.nist.gov/solubility/IUPAC/SDS-43/SDS-43.pdf

34. Sato T, Hamada Y, Sumikawa M, Araki S, Yamamoto H (2014) Solubility of oxygen in organic solvents and calculation of the hansen solubility parameters of oxygen. Ind Eng Chem Res 53:19331-19337

35. Parker J, Novakovic K (2018) The effect of using a methanol-water solvent mixture on pH oscillations in the palladium-catalyzed phenylacetylene oxidative carbonylation reaction. React Kinet Mech Catal 123:113-124

36. Parker J, Novakovic K (2013) Influence of water and the reactant addition sequence on palladium(II) iodide-catalyzed phenylacetylene carbonylation. Ind Eng Chem Res 52:2520-2527

37. Dai Z, Ronholm J, Tian Y, Sethi B, Cao X (2016) Sterilization techniques for biodegradable scaffolds in tissue engineering applications. J Tissue Eng 7:2041731416648810

38. Straube R, Flockerzi D, Müller SC, Hauser MJB (2005) Origin of bursting pH oscillations in an enzyme model reaction system. Phys Rev E 72:066205-1-066205-12

39. Bakeš D, Schreiberová L, Schreiber I, Hauser MJB (2008) Mixed-mode oscillations in a homogeneous pH-oscillatory chemical reaction system. Chaos 18:015102

Publisher's Note Springer Nature remains neutral with regard to jurisdictional claims in published maps and institutional affiliations. 